\title{
USE OF SOME ETHNOMEDICINAL HERBS BY THE NATIVES OF SOLANG VALLEY, KULLU DISTRICT, HIMACHAL PRADESH
}

\author{
MANINDER KAUR, VIJAY KUMAR SINGHAL, JASWANT SINGH
}

Punjabi University, Public University in Patiala, India

Email: maninderdhot84@gmail.com

Received: 12 Jun 2017 Revised and Accepted: 22 Jul 2017

\section{ABSTRACT}

Objective: The objective of the study was to enlist the ethnobotanical uses of wild plants of Solang Valley, Kullu District, Himachal Pardesh. Due to the specific geographical location of the valley, it possesses a high amount of endemic plant diversity. The plants are being used medically by local people against many ailments such as rheumatism, gastric disorders, muscular pain, asthma, dysentery, diabetes, constipation, cold, cough, fever, etc.

Methods: For documentation of ethnomedicinal information, a questionnaire containing vernacular name, plant part/s used, medicinal uses, method of preparation and amount of dose taken was prepared. To gather such information, personal interviews/interactions were conducted with medicine men (vaids and hakims), local healers, village elders, tribals and shepherds.

Results: Presently, 42 plant species belonging to 41 genera and 24 families are included for ethnobotanical study with respect to their scientific names, vernacular names, plant parts used, ethnomedicinal purposes, mode of preparation, and dose/amount taken. As many as 23 species are used for treating more than one ailment. By consulting the previous literature, it was found that there are 19 species which have not been reported earlier and are used by the natives for different medicinal purposes.

Conclusion: The unsustainable harvesting such as uprooting of whole plant of medicinal use from the wild is resulting into a serious decline in plant populations. Therefore various cultivation techniques should be designed, and implemented especially for the highly medicinally important and endangered plant species. Grazing should be restricted in high altitudinal zones possessing high endemic plant diversity. Further, information gathered on ethnobotanical aspects of plants of medicinal use will be helpful in the selection of elite genotypes/chemotypes which could provide a base for future plantation programmes which will be helpful for sustainable development of the valley.

Keywords: Solang Valley, Ethnobotany, Medicinal Plants, Unsustainability, Grazing

(C) 2017 The Authors. Published by Innovare Academic Sciences Pvt Ltd. This is an open access article under the CC BY license (http://creativecommons.org/licenses/by/4.0/) DOI: http://dx.doi.org/10.22159/ijpps.2017v9i9.20664

\section{INTRODUCTION}

In India, native people exploit a variety of herbs for the effective treatments of various ailments. The plant parts used, preparation, and administration of drugs vary from place to place [1]. Indigenous knowledge is as old as human civilization, but the term ethnobotany was coined by an American botanist, John Harshburger who defined it as a mean to study the plants used by primitive and aboriginal people. Since time immemorial, plants have been employed in traditional system of medicines in different parts of the world. According to the World Health Organization (WHO), as many as $80 \%$ of the world's people depend on traditional systems of medicines to meet their primary health care needs. There are considerable economic benefits stemming from the development of indigenous medicine and use of medicinal plants for the treatment of various diseases [2].

Himachal Pradesh, a Northern Indian State is a rich storehouse of medicinal herbs and people living in the vicinity of higher hills and isolated valleys especially of cold deserts of Lahaul-Spiti, Kalpa Valley, Pangi Valley, and Parvati Valley are well conversant with the medicinal use of many herbs for their daily medicinal needs. As such, the locals are quite rich in traditional knowledge about the use of several of indigenous herbs of local medicinal use. So much so, several species of medicinal herbs have been collected in mass by the traders through employing locals.

Solang Valley which has derived its name from Solang Village and the nearby Solang Nullah, is a side valley at the top of the Kullu Valley in Himachal Pradesh. It lies between latitude $32^{\circ} 16^{\prime \prime} 0 \prime \mathrm{N}$ and longitude $77^{\circ} 10^{\prime \prime} 0^{\prime} \mathrm{E}$ with an altitudinal range of $2400-3540 \mathrm{~m}$. Solang Nullah originates from Beas Kund glacier and finally merges into river Beas near village Palchan. The Valley is situated towards the North-West of the resort town Manali and is well known for its summer and winter sports. Popularly known as 'Snow-point', it offers various challenging activities of horse-riding, paragliding, skiing and zorbing. There is a beautiful view of Patalsu Peak (3963m) from Solang Valley. The trek in the valley starts along the right bank of the river Beas through villages like Palchan $(2400 \mathrm{~m})$, BRO office $(2400 \mathrm{~m})$, Bahang $(2450 \mathrm{~m})$, Schnag $(2450 \mathrm{~m})$, Burua (2450m), Vashisht Village (2475m), Goshal (2575m), Solang Nullah $(2700 \mathrm{~m})$, Solang Village $(2750 \mathrm{~m})$, Dhundhi $(3050 \mathrm{~m})$, and Rohtang Tunnel $(3100 \mathrm{~m})$ (Map 1c). Along the treks, are present glaciers and snow-capped peaks including the peaks of Deo-tibba $(6001 \mathrm{~m})$ and Indrasan (6221m).

The changing situation in the ecological zones like Solang Valley, especially the loss of habitats and habitat fragmentation is the major threat to plant diversity of the region. In highly populated areas especially around Palchan $(2400 \mathrm{~m})$ and Dhundhi $(3050 \mathrm{~m})$, original habitats are already destroyed resulting into a huge loss of endemic plant species particularly of medicinal value. Looking at the importance of traditional knowledge on locally used medicinal herbs, several workers have gathered ethnobotanical information in Himachal Pradesh [3-12] and within Himachal Pradesh, district based information has been gathered by various workers viz., Districts of Dharamshala [13], Kullu [14, 15], Parvati Valley [16-18], Lahaul-Spiti [19-27], Kangra [28-31], Mandi [32-38], Sirmaur [39]; Solan [40], Chamba [41], Hamirpur [42-45], and district Kinnaur [46-48].

Also the antimicrobial activity of some important medicinal herbs have also been gathered from some other parts of India $[49,50]$. On similar lines, authors have gathered ethnobotanical information on the plant wealth of Solang Valley, a typically isolated and unexplored valley in Kullu district. 
The age old Indian system of traditional medicine is among the one of most ancient system of medicine. Out of a sum total of 400 plant species used in the Ayurvedic or other systems of traditional medicines, $30 \%$ of the preparations are derived from roots, $14 \%$ from bark, $16 \%$ from whole plants, $5 \%$ from flowers, $10 \%$ from fruits, $6 \%$ from leaves, $7 \%$ from seeds, $3 \%$ from wood, $4 \%$ from rhizomes, and $6 \%$ from stems [51].

The occurrence of diverse ecosystems along altitudinal gradients from tropical to temperate and alpine zones with its associated array of species and genetic diversity make India one of the 12 mega- biodiversity countries of the world. The wide range of plant species helps to provide for people's needs, including the need for medicines.

\section{MATERIALS AND METHODS}

\section{Methods}

For documentation of ethnomedicinal information, a questionnaire containing vernacular name, habit and habitat, flowering and fruiting period, plant part/s used, medicinal uses, method of preparation and amount of dose taken was prepared by visiting the various localities at different altitudes of Solang Valley (see: Map 1).
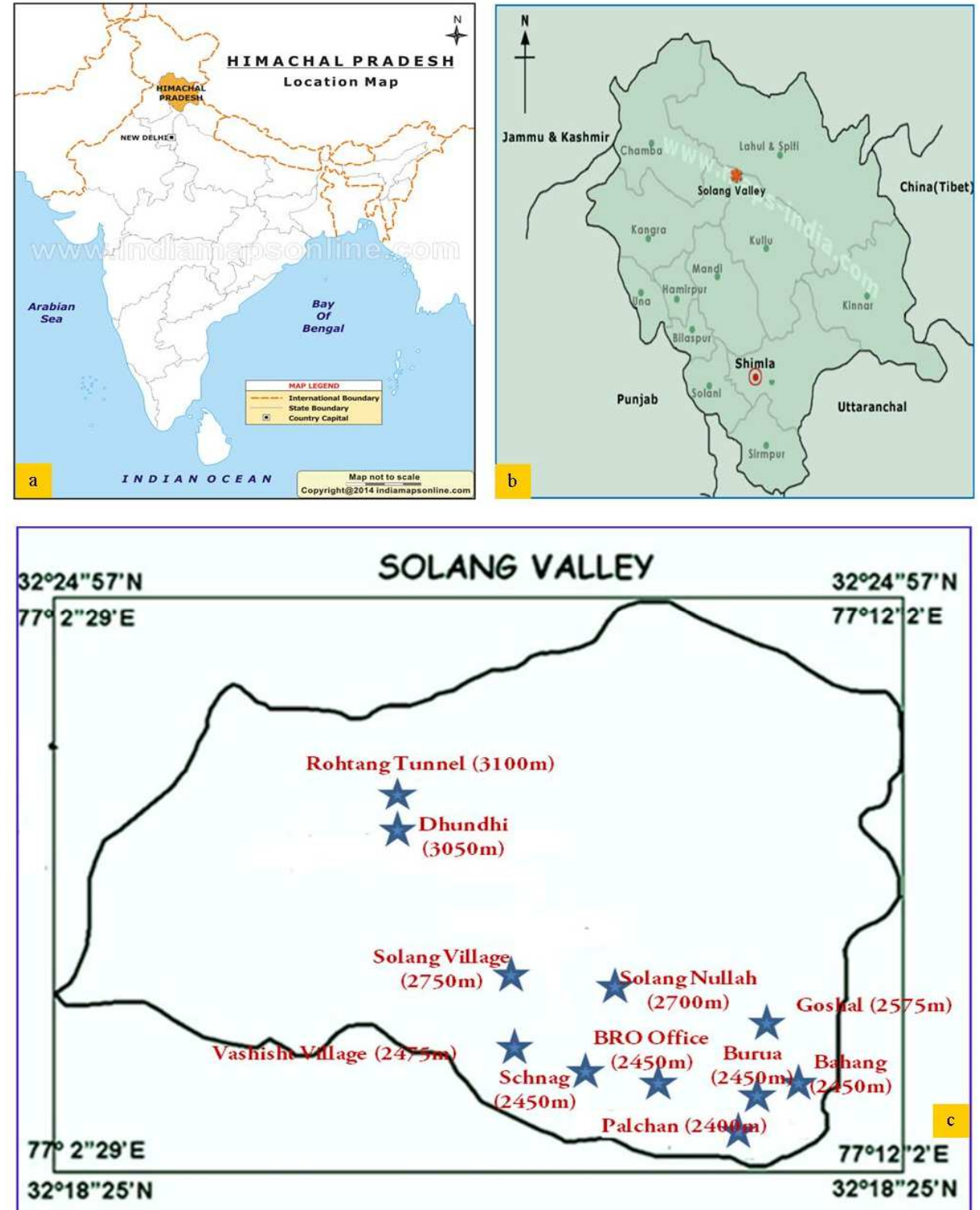

Map 1,(a-c), a) The map showing tha geographical location of Himachal Predesh in India. (b) Map showing geographical location of solang valley in kullu district, Himachal Predesh. (c) The map depicting the various localities visited during tha present study in solang valley, kullu district Himachal Predesh

To gather such information, personal interviews/interactions were conducted with medicine men (vaids and hakims), local healers, village elders, tribals and shepherds. Information about plants of herbal value was recorded as per the vernacular name/s and was further confirmed by their field photographs. The informations in each case were cross validated to ascertain the facts about the local use of each plant species.
The ethnobotanical information gathered about each plant species included vernacular/local names, ethnobotanical purposes, plant part/s used, mode of preparation, and dose/amount taken.

\section{RESULTS}

Presently, 42 plant species belonging to 41 genera and 24 families are included for ethnobotanical study with respect to their scientific 
names, vernacular names, plant parts used, ethnomedicinal uses, mode of preparation, and dose/amount taken. The plants are being used medically by local people against many ailments such as rheumatism, gastric disorders, muscular pain, asthma, dysentery, diabetes, constipation, cold, cough, fever, pneumonia, jaundice, cuts and wounds, swellings, joint pains, liver and nervous disorders, cardiac and skin problems and also in abdominal pain, headache, toothache and bodyache. Various plants are used as antiseptic, antiinflammatory, appetizer, astringent, carminative, laxative, diuretic, stimulant, tonic, antipyretic, anti-poison, calmative, aromatic, and blood purifiers. It was found that local people use various plant parts which include leaves, stem, flowers, fruits, seeds and other plant parts such as wood, bark and underground parts like rhizome. (table 1).

Table 1: Ethnobotanical information collected on some selected plant species from Solang Valley, Kullu District (Himachal Pradesh)

\begin{tabular}{lllll}
\hline $\begin{array}{l}\text { S. } \\
\text { No. }\end{array}$ & Taxon & Family & $\begin{array}{l}\text { Vernacular } \\
\text { name }\end{array}$ & $\begin{array}{l}\text { Plant p } \\
\text { used }\end{array}$ \\
\hline 1. & Achillea millefolium L. & Asteraceae & Gandana & $\begin{array}{l}\text { Leaves } \\
\text { flowers }\end{array}$ \\
& & & & Seeds \\
2. & Achyranthes bidentata Blume & Amaranthaceae & Puthkanda & Roots \\
3. & $\begin{array}{l}\text { Aconitum heterophyllum } \\
\text { Wall. ex. DC. }\end{array}$ & Ranunculaceae & Atish & Leaves \\
4. & Ageratum conyzoides L. & Asteraceae & Okalbuti &
\end{tabular}

5. Ainsliaea aptera DC.

Asteraceae

Kadvi-Booti

Roots

6. Anemone rivularis Buch.Ham. ex DC.

7. Angelica glauca Edgew.

Apiaceae

Asteraceae Clarke) Pamp. A. scoparia Waldst. and Kit.

Asteraceae

Jandrodhi

Roots

10 Berberis glaucocarpa Stapf

Berberidaceae

Kashama

Mature fruits

11. Bidens biternata (Lour.)

Merr. and Sherff (=Coreopsis

biternata Lour.)

12. Cannabis sativa $\mathrm{L}$.

13. Capsella bursa-pastoris (L.) Medik. (=Thlaspi bursapastoris $\mathrm{L}$.)

14. Cardamine impatiens $\mathrm{L}$.

15. Chenopodium album L.

16. Conyza japonica (Thunb.)

Less.

17. Corydalis cornuta Royle

18. Cynoglossum lanceolatum Forssk. (=C. micranthum Desf.)

$\begin{array}{lll}\text { Asteraceae } & \text { Lumb } & \begin{array}{l}\text { Flowers and } \\ \text { fruits }\end{array} \\ \text { Cannabaceae } & \text { Bhang } & \text { Seeds } \\ \text { Brassicaceae } & \text { Jangli Sarson } & \text { Stem } \\ \text { Brassicaceae } & \text { Mrigu } & \text { Roots } \\ \text { Chenopodiaceae } & \text { Bathua } & \begin{array}{l}\text { Fresh leaves } \\ \text { and stems }\end{array} \\ \text { Asteraceae } & \text { Gaadi } & \text { Leaves } \\ \text { Fumariaceae } & \text { Lassari } & \text { Fresh leaves }\end{array}$

Boraginaceae Balraj Whole plant

Uses

Leaves are crushed to cure tooth-ache,

dysentery, and urinary tract infections. Flowers are aromatic, carminative, laxative, stimulant and diuretic and are used to cure mumps, measles, fever, dysentery, and diabetes. Seeds are boiled in $250 \mathrm{ml}$ of water and are taken orally to cure cold, cough, mouth ulcers, whooping cough and veterinary diseases. The dry roots are powdered and taken orally with lukewarm water twice a day for 3-4 $d$ in fever.

Leaves are sun dried to make a powder. 2-3 tablespoons of powder are to be taken with cow's milk 2-3 times a day to cure headache, diarheoea, leprosy, snake bite and uterine infections.

Roots are dried and crushed in a pastle mortor in a small quantity of water, $2-3 \mathrm{~g}$ of paste are then taken orally 3-4 times with lukewarm water to relieve stomachache, constipation and acute fever.

A small piece of fresh root is put between aching teeth. The root piece is chewed for 4-5 min for toothache.

Fresh fruits are pruned along with leaves and chewed for 10-15 min to get relief from constipation, gastric ulcers, diarrhoea and vomiting.

Seeds are soaked in mustard oil for 8-10 d. Seed oil is extracted and massaged on swollen joints in case of arthritis, back pain, and bone fractures.

Fresh root part is crushed to make a thick paste which is then taken with lukewarm water to cure vomiting, bowels, cold, headache and earache.

Mature black dried fruits are collected and then grounded in a pastle mortor to make it into a smooth paste. The $1 \mathrm{~g}$ paste is then taken orally along with warm milk to get relief from menorrhazia.

Dried flowers and fruits are used medicinally to cure cuts, burns, wounds, and mouth ulcers. The plant parts are also used as an appetizer. Seed oil is extracted and is warmed by heating. The warm oil is massaged on the affected parts for arthritis.

Stem is used medicinally to cure jaundice, liver diseases, eye diseases, bodyache, headache and constipation.

Dried roots are used as diuretic, stimulant and also to cure asthma, cough, and fever.

Plant is considered as a stimulant, blood purifier and is used to cure hypothermia by making soup of its leaves in hot water. Leaf paste is used to cure eczema, skin diseases, itching, jaundice and leucoderma. Fresh leaves are grounded to prepare a juice along with equal quantities of water. The juice is taken orally in case of bone fractures, torn ligaments to heal them faster and better. Whole plant is used to cure asthma, anaemia, antifertility, and urine complaints. 


\begin{tabular}{|c|c|c|c|c|c|}
\hline 19. & Datura stramonium L. & Solanaceae & Dhatura & Dried seeds & $\begin{array}{l}\text { Dried seeds are roasted on iron pan and } \\
\text { powdered after cooling. The powder is mixed } \\
\text { with hot mustard oil to make a paste. A thick } \\
\text { paste is applied on the affected parts at bed } \\
\text { time in case of arthritis. }\end{array}$ \\
\hline 20. & $\begin{array}{l}\text { Delphinium denudatum Wall. } \\
\text { ex Hook. f. and Thoms. (=D. } \\
\text { pauciflorum Royle) }\end{array}$ & Ranunculaceae & Salyan & Rhizome & $\begin{array}{l}\text { Dried rhizome is powdered and } 1 \text { tablespoon is } \\
\text { taken orally with hot cow's milk at night for } 5-6 \\
d \text { to relieve constipation and hypothermia. }\end{array}$ \\
\hline 21. & Dicliptera bupleuroides Nees & Acanthaceae & Banbuti & Fresh leaves & $\begin{array}{l}\text { Fresh leaves are plucked and rubbed against } \\
\text { the cut wound to stop bleeding. }\end{array}$ \\
\hline 22. & Gentiana kurroo Royle & Gentianaceae & Neelkanthi & Fresh leaves & $\begin{array}{l}\text { The leaves are boiled in water and filtered. The } \\
\text { extract is taken orally for fever. }\end{array}$ \\
\hline 23. & Geranium nepalense Sweet & Geraniaceae & Ratanjot & Roots & $\begin{array}{l}\text { Roots are used locally to cure diarrohea, } \\
\text { dysentery, fever, snake bite, and vomiting. }\end{array}$ \\
\hline 24. & Gomphogyne cissiformis Griff. & Cucurbitaceae & Bel phal & Fruits & $\begin{array}{l}\text { Fresh fruits are eaten by the locals to cope with } \\
\text { anaemia especially during blood loss. }\end{array}$ \\
\hline 25. & Hypericum elodeoides Choisy & Hypericaceae & Vasanti & Whole plant & $\begin{array}{l}\text { Whole plant is used as a laxative and is used to } \\
\text { cure constipation, anthelmintic, parasiticide, } \\
\text { antifungal, ascariasis, and diuretic. }\end{array}$ \\
\hline 26. & Lactuca dissecta D. Don. & Asteraceae & Mogri & Roots & $\begin{array}{l}\text { Dried roots are powdered, stored and rubbed } \\
\text { against snake bite by making a paste in water. } \\
\text { Powder is also taken orally to cure bodyache, } \\
\text { cuts, burns, inflammations, vomiting, and } \\
\text { mental disorders. }\end{array}$ \\
\hline 27. & Mentha longifolia (L.) L. & Lamiaceae & Jangli podina & Leaves & $\begin{array}{l}\text { Leaves are crushed to make a smooth paste } \\
\text { and are eaten to cure diaorrhea, dysentery and } \\
\text { vomiting. }\end{array}$ \\
\hline 28. & Ocimum sanctum $\mathrm{L}$. & Lamiaceae & Tulsi & Root and leaves & $\begin{array}{l}\text { Decoction of the roots and leaves is given in } \\
\text { case of malarial fever. }\end{array}$ \\
\hline 29. & Origanum vulgare $\mathrm{L}$. & Lamiaceae & Ban-tulsi & Leaves & $\begin{array}{l}\text { Fresh leaves are chewed to fix cough, cold and } \\
\text { breathing problems. }\end{array}$ \\
\hline 30. & Oxalis corniculata $\mathrm{L}$. & Oxalidaceae & Khatti-Meethi & Fresh leaves & $\begin{array}{l}\text { Fresh juice of leaves is useful in gum problems } \\
\text { and dysentry. Children pluck the leaves and } \\
\text { chew them for its sweet and sour taste. }\end{array}$ \\
\hline 31. & $\begin{array}{l}\text { Picrorhiza kurooa Royle ex } \\
\text { Benth. }\end{array}$ & Scrophulariaceae & Karu & Leaves & $\begin{array}{l}\text { Dry leaves are boiled in water and decoction is } \\
\text { prepared. The decoction is taken orally once a } \\
\text { day for cold and cough. }\end{array}$ \\
\hline 32. & Plantago major L. & Plantaginaceae & Carrata, Therma & Leaves & $\begin{array}{l}\text { Slightly warmed leaves applied with mustard } \\
\text { oil are kept on boils overnight to burst it out. It } \\
\text { is believed that it reduces both swelling and } \\
\text { pain. }\end{array}$ \\
\hline 33. & $\begin{array}{l}\text { Plectranthus rugosus Wall. ex } \\
\text { Benth. }\end{array}$ & Lamiaceae & Pasak & Leaves & $\begin{array}{l}\text { Leaves are sun dried, powdered and taken } \\
\text { orally for the purification of blood, } \\
\text { stomachache and acidity. }\end{array}$ \\
\hline 34. & $\begin{array}{l}\text { Podophyllum hexandrum } \\
\text { Royle }\end{array}$ & Podophyllaceae & Ban-kakdi & Roots & $\begin{array}{l}\text { Roots are washed, sun dried and then roasted } \\
\text { in a little mustard oil. Roasted roots are then } \\
\text { grounded to make it a smooth paste. The paste } \\
\text { is consumed alongwith food } 2-3 \text { times to } \\
\text { relieve from stomach bowels, flatulence and } \\
\text { other gastric problems. }\end{array}$ \\
\hline 35. & $\begin{array}{l}\text { Persicaria amplexicaulis (D. } \\
\text { Don) R. Decr. } \\
\text { (=Bistorta amplexicaulis (D. } \\
\text { Don) Greene) }\end{array}$ & Polygonaceae & Rambha & Roots & $\begin{array}{l}\text { Dried roots are grounded to make a paste and } \\
\text { then applied on boils. }\end{array}$ \\
\hline 36. & $\begin{array}{l}\text { Ranunculus laetus Wall. ex } \\
\text { Hook. f. and Thoms. }\end{array}$ & Ranunculaceae & Mingo & Roots & $\begin{array}{l}\text { Fresh roots are grounded and the paste is } \\
\text { applied on wounds overnight. }\end{array}$ \\
\hline 37. & Rumex dentatus $\mathrm{L}$. & Polygonaceae & Jangli-Palak & Roots & $\begin{array}{l}\text { Dried roots are used to cure against any type of } \\
\text { poison. }\end{array}$ \\
\hline 38. & $\begin{array}{l}\text { Senecio nudicaulis Buch.- } \\
\text { Ham. ex D. Don }\end{array}$ & Asteraceae & Ratpati & Flowers & $\begin{array}{l}\text { Fresh flowers are boiled in milk up to } 10-15 \\
\text { min and then taken orally to cure cough and } \\
\text { cold. }\end{array}$ \\
\hline 39. & Sigesbeckia orientalis L. & Asteraceae & Dachroo & Roots & $\begin{array}{l}\text { Dried roots are powdered, make a paste with } \\
\text { water. The paste is then mixed with cooked } \\
\text { vegetables to cure mouth, throat, eczema and } \\
\text { other skin diseases. }\end{array}$ \\
\hline 40. & $\begin{array}{l}\text { Silene vulgaris (Moench) } \\
\text { Garcke }\end{array}$ & Caryophyllaceae & Gandoli & Whole plant & $\begin{array}{l}\text { Whole plant is cooked as vegetable and is } \\
\text { considered to be good in cold treatment and } \\
\text { digestive in nature. }\end{array}$ \\
\hline 41. & Taraxacum officinale Wigg. & Asteraceae & Dhudhee & Leaves & $\begin{array}{l}\text { Fresh leaves are crushed to make a paste which } \\
\text { is supposed to be diuretic and blood purifier. }\end{array}$ \\
\hline 42. & $\begin{array}{l}\text { Thalictrum foliolosum DC. } \\
\text { (=Thalictrum dalingo Buch.- } \\
\text { Ham. ex DC.) }\end{array}$ & Ranunculaceae & Pilijari & Leaves & $\begin{array}{l}\text { Fresh leaves are kept in storage of grains in } \\
\text { drums to avoid grain infestation. }\end{array}$ \\
\hline
\end{tabular}

Among various plant parts, leaves (33.33\%) are the mostly frequently used, followed by roots (31.11\%), fruits (8.89\%), seeds (8.89\%), flowers (6.67\%), and stem (4.44\%) while in $6.67 \%$ cases whole plant is used for different medicinal purposes (fig. 1). 


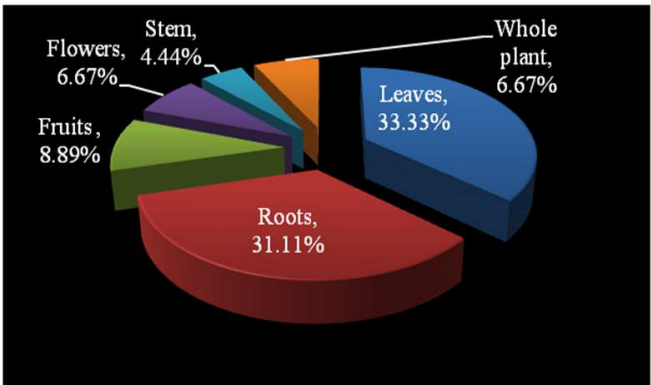

Fig. 1: \% age of various plant parts used for ethnobotanical purposes

\section{DISCUSSION}

As many as 23 species such as, Achillea millefolium, Achyranthes bidentata, Ageratum conyzoides, Ainsliaea aptera, Angelica glauca, Artemisia nilagirica, A. scoparia, Bidens biteranata, Capsella bursa-pastoris, Cardamine impatiens, Chenopodium album, Conyza japonica, Cynoglossum lanceolatum, Delphinium denudatum, Geranium nepalense, Hypericum elodeoides, Lactuca dissecta, Mentha longifolia, Oxalis corniculata, Plectranthus rugosus, Podophyllum hexandrum, Siegesbeckia orientalis, and Taraxacum officinale are used for treating more than one ailment. By consulting the previous literature, it was found that there are 19 species viz., Achyranthes bidentata, Ageratum conyzoides, Anemone rivularis, Artemisia nilagirica, Berberis glaucocarpa, Bidens biteranata, Cannabis sativa, Cardamine impatiens, Chenopodium album, Conyza japonica, Cynoglossum lanceolatum, Delphinium denudatum, Dicliptera bupleuroides, Gomphogyne cissiformis, Hypericum elodeoides, Origanum vulgare, Plantago major, and Silene vulgaris which have not been reported earlier and are used by the natives for different medicinal purposes.

As the Solang Valley is situated at the border of Great Himalayas and Trans-Himalaya and due to its strategic geographical location, it harbours endemic plant diversity of both the ecological conditions. The study also reveals that the natives are still dependent upon their surrounding plant resources to fulfil their day-to-day needs and for traditional healing system. Present study explores information for the first time from the Solang Valley for various ethnomedicinal purposes such as gastric disorders, joint pains, skin disorders, cuts, wounds, burns, snake bites, fever, anaemia, hypothermia, cold, cough, and many other diseases. By comparing the previous literature regarding ethnobotanical information gathered by other workers from different parts of Himachal Pradesh, it was found that a number of species with unreported uses or new uses with different plant parts used and also with new mode of use have been recorded from the study area.

Despite imposing the ban by the government in the study area, there is a heavy exploitation of roots of highly medicinally important plant species such as, Aconitum heterophyllum, Ainsliaea aptera, Angelica glauca, Artemisia nilagirica, Berberis glaucocarpa, Cardamine impatiens, Mentha longifolia, Picrorhiza kurroa, Podophyllum hexandrum, and Senecio nudicaulis which are sold to the traders by the tribals to fulfill their household needs resulted into severe decrease in their population size. As a consequence some herbs are now restricted to small pockets in the study area. Another matter of great concern in the study area is the serious threats posed by grazing especially in the sub-alpine and alpine regions to species which fall under the IUCN-World Conseravtion Union's Red list of threatened species such as Aconitum heterophyllum, Podophyllum hexandrum, Ainsliaea aptera, and Picrorhiza kurroa.

Keeping in view the importance of endemic plant diversity and also to conserve the highly important but rare medicnal herbs present in the valley, immediate steps must be taken up to formulate an action plan to preserve the ethnic knowledge and about the distribution of medicinal herbs in the region. Further, it is suggested that we should follow this year's UNEP theme of World Conservation Day that is 'Go Wild for Life' that visualizes us to ascertain all those species which are under threat and to take an action to conserve them for future generations. It is rightly said that local level extinctions are followed by global level extinctions. Another important aspect in this arena is to educate and create employment opportunities for the younger generation regarding the ethnic knowledge in the region.

The unsustainable harvesting such as uprooting of whole plant of medicinal use from the wild is resulting into a serious decline in plant populations. It is thus recommended that cultivation techniques should be designed, and implemented especially for the highly medicinally important and endangered plant species. Grazing should be restricted in areas which are much prone to natural calamities and in some high altitudinal regions with high endemic plant diversity. Further, information gathered on ethnobotanical aspects of plants of medicinal use will be helpful in the selection of elite genotypes/chemotypes which could provide a base for future plantation programmes for sustainable development. Interestingly, inspite of extensive and intensive surveys, the author could not locate even a single individual of some important medicinal herbs viz., Dactylorhiza hatagirea, Meconopsis aculeata, Rheum emodii, Saussurea costus, S. obvallata, and Valeriana jatamansi. All the mentioned species falls under IUCN-World Conservation Union's list of threatened species.

\section{ACKNOWLEDGEMENT}

The study was supported by financial grant under DRS SAP I, SAP II and SAP III of UGC and IPLS project of DBT (BT/PR4548/INF/22/146/2012), and UGC for providing financial assistance to Maninder Kaur under Maulana Azad National Fellowship Scheme (Award letter no. F1-17.1/2011/MANF-SIKHAR-4278/(SA-III/Website), and Jaswant Singh under Basic Scientific Research Fellowship scheme (Award letter no. 15610/Research/03/06/2015).

\section{CONFLICT OF INTERESTS}

\section{Declared none}

\section{REFERENCES}

1. Verma AK, Kumar M, Bussmann RW. Medicinal plants in an urban environment: the medicinal flora of Banares Hindu University, Varanasi, Uttar Pradesh. J Ethnobiol Ethnomed 2007;3:35-9.

2. Azaizeh H, Fulder S, Khalil K, Said O. Ethnobotanical knowledge of local Arab practitioners in the Middle Eastern region. Fitoterapia 2003;74:98-108.

3. Sharma OP. Some useful wild plants of Himachal Pradesh, College of Biosciences. HPU, Shimla; 1976.

4. Lal B, Vats SK, Singh RD, Gupta AK. Plants used as ethnomedicine and supplement found by the Gaddis of Himachal Pradesh, India. In: Jain SK. ed. Ethnobiology in Human Welfare. Deep Publ., New Delhi; 1996. p. 384-7.

5. Chauhan NS. Medicinal and Aromatic Plants of Himachal Pradesh. Indus Publ. Co., New Delhi; 1999.

6. Sharma BD, Rana, JC. Traditional uses of plants of Himachal Pradesh hills. J Econ Taxon Bot 1999;23:173-6.

7. Badola HK. Medicinal plant diversity of Himachal Pradesh. In: Samant SS, Dhar U, Palni LMS. eds. Himalayan Medicinal Plants: Potential and Prospects; Gyanodaya Prakashan, Nainital; 2001. p. 87-116.

8. Sharma PK, Lal B. Ethnobotanical notes on some medicinal and aromatic plants of Himachal Pradesh. Indian J Traditional Knowledge 2005;4:424-8.

9. Gautam AK, Bhatia MK, Bhadauria R. Diversity and usage custom of plants of South Western Himachal Pradesh, India. Int J Phytol Ethnobot 2011;3:24-36.

10. Gupta P, Sharma VK. Reckoning the ethnobotanical wisdom of communities living in the lower Sutlej basin of Himachal Himalayas. LSL 2013;3:55-69.

11. Rani S, Rana JC, Jeelani SM, Gupta RC, Kumari S. Ethnobotanical notes on 30 medicinal polypetalous plants of district Kangra of Himachal Pradesh. J Med Plants Res 2013;7:1362-9.

12. Kumar P, Singhal VK. Ethnobotany and ethnomedicinal uses, chromosomal status and natural propagation of some plants of 
Lahaul-Spiti and adjoining hills. J Bot 2013 http://dx.doi.org/10.1155/2013/248943

13. Uniyal MR, Chauhan NS. Traditionally important medicinal plants of Kangra Valley in Dharamsala Forest Circle, Himachal Pradesh. J Res Indian Med 1973;8:76-85.

14. Uniyal MR, Chauhan NS. Commercially improtant medicinal plants of Kullu Forest Division of Himachal Pradesh. Nagarjuna 1982;4:28-32.

15. Singh SK. Ethnobotanical study of useful plants of Kullu district in Northwestern Himalayas, India. J Econ Taxon Bot 1999;23:185-98.

16. Sharma PK, Chauhan NS, Lal B. Commercially important medicinal and aromatic plants of Parvati Valley, Himachal Pradesh. J Ecol Taxon Bot 2003;27:937-42.

17. Sharma PK, Chauhan NS, Lal B. Observations on the traditional phytotherapy among the inhabitants of Parvati Valley in Western Himalaya India. J Ethnopharmacol 2004;92:167-76.

18. Himshikha. Cytomorphological explorations of dicots from parvati valley in kullu district (Himachal Pradesh). Ph. D. Thesis, Pbi. Univ., Patiala; 2014.

19. Koelz WN. Notes on the ethnobotany of Lahaul, a province of the Punjab. Quart J Crude Drug Res 1979;17:1-56.

20. Uniyal MR, Bhat HV, Chaturvedi PN. Preliminary observation on medicinal plants of Lahaul and Spiti forest division in Himachal Pradesh. Bull Med-Ethno-Bot Res 1982;3:1-26.

21. Kapahi BK. Ethno-botanical investigation in Lahaul (Himachal Pradesh). J Ecol Taxon Bot 1990;14:49-55.

22. Srivastava TN, Kapahi BK, Sarin YK. Ethnobotanical studies in Lahaul and Spiti, Himachal Pradesh. Ancient Sci Life 1992;11: 126-30.

23. Chandra Sekar K, Srivastava SK. Traditional uses of plants in curing jaundice in the Pin Valley National Park, Himachal Pradesh. Indian J Traditional Knowledge 2005;4:314-6.

24. Singh V, Chauhan NS. Traditional practices of herbal medicines in the Lahaul valleys, Himachal Himalayas. Indian J Traditional Knowledge 2005;4:208-20.

25. Lal B, Singh KN. Indigenous herbal remedies used to cure skin disorders by the natives of Lahaul-Spiti in Himachal Pradesh. Indian J Traditional Knowledge 2008;7:237-41.

26. Singh KN. Ecological Studies on Landscape Elements, Species Diversity and Ethnobotany of Higher Plants in Lahaul-Spiti Region of Western Himalaya. Ph. D. Thesis; HNB Garhwal Univ., Srinagar Garhwal, India; 2008.

27. Singh KN, Lal B. Ethno-medicines used by tribal communities against four common ailments in Lahaul-Spiti, Western Himalaya. J Ethnopharm 2008;115:147-59.

28. Sharma PK, Chauhan NS. Ethnobotanical studies of Gaddi-a tribal community of Kangra district, Himachal Pradesh. In: Kohli RK, Singh HP, Vij SP, Dhar KK, Batish DR, Dhiman BK, eds. Man and Forest. Panjab Univ., Chandigarh; 2000. p. 301-2.

29. Uniyal SK, Singh KN, Jamwal P, Lal B. Traditional use of medicinal plants among the tribal communities of Chhota Bhangal, Western Himalaya. J Ethnobiol Ethnomed 2006;2:1-8.

30. Uniyal SK, Sharma V, Jamwal P. Folk medicinal practices in Kangra district of Himachal Pradesh, Western Himalaya. J Hum Ecol 2011;39:479-88.

31. Rani S, Rana JC, Jeelani SM, Gupta RC, Kumari S. Ethnobotanical notes on 30 medicinal polypetalous plants of district Kangra of Himachal Pradesh. J Med Plant Res 2013;7:1362-9.

32. Gaur RD, Singh PB. Ethnomedicinal plants of Mandi district, Himachal Pradesh. Bull Med-Ethno-Bot Res 1993;14:1-11.

33. Singh PB. Medicinal plants of ayurvedic importance from Mandi district of Himachal Pradesh. Bull Med-Ethno-Bot Res 1993;14:126-36.
34. Singh PB. Wild edible plants of Mandi district in Northwest Himalaya. In: Jain SK. ed. Ethnobiology in Human Welfare; Deep Publ., New Delhi; 1996. p. 22-5.

35. Thakur S. Study on the Ethnobotany of Rewalsar (Mandi District, Himachal Pradesh, India). Ph. D. Thesis: H. P. Univ., Shimla; 2001.

36. Sood SK, Thakur S. Ethnobotany of Rewalsar Himalaya: Deep Publications, New Delhi; 2004.

37. Kaur I, Sharma S, Lal S. Ethnobotanical survey of medicinal plants used for different diseases in Mandi district, Himachal Pradesh. Int J Pharm Chem 2011;1:1167-71.

38. Sharma P, Patti P, Agnihotry A. Ethnobotanical and ethnomedicinal uses of floristic diversity in Murari Devi and surrounding areas of Mandi district in Himachal Pradesh, India. Pakistan J Biol Sci 2013;16:451-68.

39. Kaur H, Sharma M. Flora of sirmaur (Himachal Pradesh). Bishen Singh and Mahendra Pal Singh, Dehra Dun; 2004.

40. Verma S, Chauhan NS. Indigenous medicinal plants knowledge of Kunihar forest division, district Solan. Indian J Traditional Knowledge 2007;6:494-7.

41. Rana PK, Kumar P, Singhal VK, Rana JC. Uses of local plant biodiversity among the tribal communities of Pangi Valley of district Chamba in cold desert Himalaya, India. Sci World J 2013. http://dx.doi.org/10.1155/2014/753289

42. Rawat DS, Kharwal AD, Rawat S. Ethnobotanical studies on dental hygiene in district Hamirpur, Himachal Pradesh (H. P.), India. Ethnobot Leaflets 2009;13:1434-42.

43. Kumar N, Choyal R. Traditional use of some plants of Hamirpur district of Himachal Pradesh for the treatment of jaundice, hepatitis and other liver disorders. Int J Theor Appl Sci 2012;4:201-5.

44. Kumar N, Choyal R. Traditional health cure practices used for respiratory disorders by the rural people of Hamirpur district of Himachal Pradesh. LSL 2013;4:41-50.

45. Kumar S, Sharma SD, Kumar N. Ethnobotanical study of some common plants from district Hamirpur of Himachal Pradesh (India). Int J Adv Res 2015;3:492-6.

46. Negi PS, Subramani SP. Ethnobotanical study in village Chhitkul of Sangla Valley, Kinnaur district, Himachal Pradesh. J NonTimber Forest Prod 2002;9:113-20.

47. Kaur D, Singhal VK. Chromosome counts, male meiotic studies and ethnobotanical uses in selected medicinal herbs from Kinnaur district of Himachal Pradesh (India). World J Pharm Pharm Sci 2016;5:912-35.

48. Kumari K, Saggoo MIS. Cytomorphology of some medicinal grasses from Hangrang Valley of District Kinnaur, Himachal Pradesh. Int J Pharm Pharm Sci 2016;8:187-90.

49. Jegadeeshwari LA, Dharathi N, Lakshmi DV, Kumar EV, Gandhi NN. Tribal plants and their inborn antimicrobial activities. Asian J Pharm Clin Res 2017;10:31-7.

50. Manikandan D, Jegadeeshwari LA, Gandhi NN. Biological activity sources from traditionally used tribe and herbal plants material. Asian J Pharm Clin Res 2015;8:11-23.

51. Kumar M, Sheikh MA, Bussmann RW. Ethnomedicinal and ecological status of plants in Garhwal Himalaya, India. J Ethnobiol Ethnomed 2011;7:32.

\section{How to cite this article}

- Maninder Kaur, Vijay Kumar Singhal, Jaswant Singh. Use of some ethnomedicinal herbs by the natives of solang valley, Kullu District, Himachal Pradesh. Int J Pharm Pharm Sci 2017;9(9):222-227. 